\title{
Islamic Perspectives on Basic Income
}

\author{
Abdullah Al-Shami and Katherine Bullock
}

\begin{abstract}
This article presents Islamic perspectives on the concept of Basic Income, and examines its emergence with the first Islamic society established at the time of the Prophet Muhammad. The scope of this research is to provide a historical account of Islamic society's and Qur'anic foundations of social justice; to provide Islamic definitions of the concepts involved in the Basic Income debate (such as wealth, poverty, and work); and to discuss the Islamic approach to Basic Income. Finally, the research will consider Islamic perspectives on the role of charity and the use of natural resources as sources of revenue to fund Basic Income.
\end{abstract}

\section{Introduction: Provision of Basic Income and Islamic Approaches}

As governments strive to address growing inequality, the shortcomings of the welfare state, technological challenges to the labor-force, the rise of the precariat, and the changing nature of work in the twenty-first century, the

\footnotetext{
Abdullah Al-Shami is a Professor of Arabic and Islamic Studies and now research fellow at The Tessellate Institute, a non-profit research institute in Canada. He obtained his ILB in Islamic Law, ILM Degree in Comparative Islamic Jurisprudence from Saudi Arabia, and $\mathrm{PhD}$ in Comparative Islamic Jurisprudence from the University of Manchester, UK. He has written and edited over ten books and over 60 research articles on Islamic Law and Islamic Studies.

Katherine Bullock, Research Advisor at The Tessellate Institute, received her $\mathrm{PhD}$ in political science from the University of Toronto (1999). She is a Lecturer in the Department of Political Science, University of Toronto at Mississauga. Her publications include Muslim Women Activists in North America: Speaking for Ourselves, and Rethinking Muslim Women and the Veil: Challenging Historical and Modern Stereotypes, which has been translated into Arabic, French, Malayalam, and Turkish. The argument developed in this paper was presented at the conference "The Case for Solidarity: Multi-Faith Perspectives on Basic Income," held at University of St. Michael's College, Toronto, Canada, on October 20, 2017.
} 
concept of Basic Income is gaining traction. In an interview with Wired, US President Barack Obama agreed that in the coming years, conversations over Basic Income are a "debate we'll be having." In 2016 the government of Ontario, Canada, as well as Finland and Kenya, announced pilot projects to study its implementation. ${ }^{2}$

Basic Income (BI), an idea with different names (Guaranteed Annual Income, Unconditional Basic Income, Universal Basic Income, Citizen's Income, Social Dividend, Universal Grant, Demogrant...), has a fundamental aim of ensuring everyone an income that is sufficient to meet their basic needs and the right to live a life of dignity, regardless of their work status.

$\mathrm{BI}$ is a concept attractive to many across the political and philosophical spectrum. Over the past fifty years it has been explored largely through the secular lenses of dignity, autonomy, justice, feminism, and economics. ${ }^{3}$ Faith-based communities have an important role to play in government initiatives potentially supportive of social justice. Thus while it may be that Basic Income is not in the lexicon of most religions, the concepts that support it certainly are. In Ontario a multifaith network arose to explore and support the previous Ontario government's pilot project on Basic Income.

Muslims have been largely absent from these debates over BI. Indeed, an extensive literature review has not turned up any discussions of Muslim perspectives on Basic Income. This is likely because the debate over BI often centers on how best to alleviate poverty, and Muslims have their own system of zakāt and charity to address that issue. Public policy and normative discussions on this topic by Muslims are couched in the language of "distributive justice," and focused on Muslim countries or political theory, yet it quickly becomes clear that what is being discussed is practically identical to the concept of Basic Income. ${ }^{4}$ As citizens of secular liberal-democracies in which debates over BI are taking place, it is important for Muslims to play a role in these public-policy related debates. For, as Siddiqui points out, the Islamic view of life is "essentially spiritual and ethical,"5 let alone given the practical exigencies of material existence. In western societies, moreover, Muslims are often recipients of welfare, so it behooves Muslim thinkers to contemplate best practices in poverty alleviation. Although BI is bigger than poverty alleviation, that aspect is a large part of its rationale.

Hence, this paper explores Islamic approaches to Basic Income. After setting out a brief explanation of two different kinds of delivery systems for $\mathrm{BI}$, the paper will consider from an Islamic point of view some of the important themes that arise in BI discussions. Part One explores the concept of social justice to demonstrate that Islamic views on the state's responsi- 
bility for guarding the welfare of its citizens are closely aligned, albeit not identical, with many ideas that inform the concept of basic income. It is important to understand that the main objective of this paper is to demonstrate this symmetry for western public policy debates. The aim is not to define nor examine how Basic Income could be integrated into a sharia-based system; the sharia already has mechanisms for addressing the main issues Basic Income addresses. We aim to introduce certain Islamic concepts to a western debate, in order to demonstrate that Muslim citizens in western countries could support Basic Income proposals from the point of view of certain Islamic precepts. So, to this end, section one develops several core ideas: aims and purposes of Islamic law; wealth; poverty; and work. Part Two looks at the sources of revenue that fund state expenditures. Part Three briefly considers some historical examples of Islamic versions of the Basic Income provision. All this represents only a modest beginning in Muslim perspectives on the Basic Income concept for a western context.

\section{Part One: Negative Income Tax and the Demogrant}

The pilot project in Ontario was based on the Negative Income Tax (NIT) model of BI. ${ }^{6}$ In this model, when a person's income fell below a set amount (in Ontario's case, under $\$ 34,000$ /year for a single adult or under $\$ 48,000$ / year for a couple), they began receiving money from the government. Although there are certain similarities with welfare models, the most significant difference is that eligibility and work requirements were not attached to the money. BI advocates argue that a NIT is better than welfare precisely for these two reasons; the welfare system is patronizing, policing, dehumanizing, embarrassing and degrading to recipients, representing a loss in their autonomy as human beings. ${ }^{\text {? }}$

The demogrant model is based on a similar critique of the welfare system; however, its delivery is markedly different from that of NIT, in that under a demogrant, all citizens of the country receive an amount of money, irrespective of their current income status. The demogrant raises the ire of many people precisely because of this, but its defenders are able to offer convincing philosophical rationales. Van Parijs, ${ }^{8}$ for example, argues for a demogrant based on 3 reasons: 1) individualism: in the twenty-first century we are not aware of what kinds of living arrangements people have, whether or not they are married, co-habiting, just friends, and so on; there is no need for the state to police this in order to determine varying rates; 2) universal: while this would give money to the rich as well as the poor, it is counter-intuitively a measure that protects the poor, because 
it allows people to avoid the poverty trap; in the current welfare systems, once people earn over a certain amount, their welfare is reduced, providing a disincentive to work; and 3) unconditional (not tied to work schemes): in our current societies, many people are over-worked, leaving them little time for family, civic engagement, friends, or hobbies. The demogrant thus solves the problem of both under- and over-employment, by giving people a stable amount of money on which to live, while they attend to other equally important aspects of living a flourishing human life. Taxation can ensure the wealthy are not unfairly given precedence, as the whole concept of the BI itself is based on the aim of a fairer distribution of natural and value-added resources amongst all citizens of a society. ${ }^{9}$

\section{The Concept of Basic Income in the Shari'a}

Given that, as we mention below in the section on work, Islam strongly encourages Muslims to secure their needs through work, Muslim jurists have not discussed a concept similar to BI if it is defined as an "unconditional universal basic income (UUBI) [in which] every citizen will be entitled to a basic income that frees them from the necessity of having a paid job." ${ }^{10}$ However, the jurists did develop concerns about the need to address pover-

ty in society. Zakāt in fact comes to seem very close to the Negative Income Tax model proposed in the Ontario government pilot. This and other institutions are addressed further below. The sharia proposed broad principles of poverty alleviation, thus allowing variety in remedy according to time and place. In this regard, juristic literatures have thoroughly and comprehensively discussed the objectives of the sharia, specifically under the two principles of darūriyāt (necessities) and hājiyāt (needs). These principles thus furnish Muslim citizens with the tools to support BI initiatives in western countries based on Islamic precepts.

Western debates on Basic Income center around the role of the state in economic life, uniquely attracting support from the right (which seeks to reduce the role of the state) and the left (which seeks to expand it). ${ }^{11}$ For Muslim scholars, as Azmi put it, "the state is regarded as an agency acting for the provision of the collective wants of the citizens." ${ }^{12}$ While often locating social services in civil society and not necessarily the State, nevertheless from the first Islamic century onwards, Muslim scholars discussed the moral obligation of authorities to help realize the wellbeing of all, preserve the interest of the people, and maintain the stability and growth of the economy. The jurists concluded that the market mechanism alone cannot perform all economic functions and that public policy is needed to guide, 
correct, and supplement the private sector. Al-Mawardi (d. 972/1058) stated: "the ruler is responsible for the welfare of the people and must do everything that he considers good for them." ${ }^{13}$

Fulfilment of the population's needs falls under the legal category of a socially obligatory duty (fard kifāya), which generally encompasses matters related to public interest. ${ }^{14}$ The eminent Shāfíi jurist al-Nawawi (d. 676/1277) stated that socially obligatory duties include the elimination of suffering through provision of clothes to the unclad and food to the hungry. ${ }^{15}$ Furthermore, Islamic jurists consider the state's resources as a trust that must be utilized for the welfare of the people. Therefore, ensuring the fulfilment of the population's basic needs is the ultimate responsibility of the State, and belongs to its core functions. As the renowned jurist al-Ghazali (d. 505 /1111) stated:

It is incumbent on the ruler to help the people when they are facing scarcity, starvation and suffering, especially during a famine or when prices are high, and people fail to earn a living in these circumstances and it becomes difficult for them to make both ends meet. The ruler should, in these circumstances feed the people and give them financial assistance from their treasury in order to improve their lot. ${ }^{16}$

The religion of Islam is not limited to spirituality alone; it is intended as a universal religion that concerns itself with community affairs, and whose purpose includes guaranteeing the general welfare of society. Prophet $\mathrm{Mu}-$ hammad (upon him blessings and peace) advised his companions to think of others in their society with compassion and fellow feeling, saying: "The believers in their mutual kindness, compassion, and sympathy are just like one body. When one of the limbs suffers, the whole body responds to it with wakefulness and fever." ${ }^{17}$ Human beings require each other's community and assistance in order to live and thrive.

We can distinguish two kinds of social solidarity between Muslims: moral and material. Moral solidarity arises from distinguishing what is good from what is bad, and from hearing the word of God and accepting it with gratitude. Material solidarity involves accepting the needs of the society and helping others to achieve what is good. Islam envisions the ideal society as one that has solid relationships between its people; in other words, the path that leads to the betterment of society is the same path that ensures that society's strength. ${ }^{18}$

The first Islamic society was established on the core values of virtue, justice, cooperation, and equality of citizens in their rights and duties (with 
every right having a corresponding duty), without discrimination based on race, religion, or language. ${ }^{19}$ The Qur'an itself repeatedly emphasizes foundational elements of justice: equality (musāwāt), moderation (i'tidāl, tawāsut), trust (amāna), and solidarity (ta'āwun). In Islam, humanity is differentiated in God's eyes only on the basis of taqwā (being Godfearing or God-conscious).

Hassan writes that "the term of social justice is generally applied to economic justice or just distribution of economic duties and rewards." ${ }^{20}$ Social justice aims "to assemble and establish the external conditions required by every citizen, for the development of his [sic] capacities." ${ }^{21}$ Social justice according to Muslim scholarship is about more than just economics: it encompasses ethics and moral values, education as well as legislation. In other words, Islam combines social and legal justice through its moral teachings and legislation.

The Qur'an repeatedly calls for feeding the poor, praising individuals who do so: "[The truly virtuous are those who] feed a wretch, an orphan and a captive" (Q 76:8; 107:2-30). Additionally, the Qur'an repeatedly condemns the mistreatment of the poor and the love of wealth, such as this passage from Surat al-Fajr:

As for [the] human being, whenever his [sic] Lord tests him by honouring him and favouring him, he says, "My Lord's honoured me." And whenever He tests him by limiting his provision, he says, "My Lord's humbled me." No way! You do not honour the orphan. And do not urge the feeding of the wretch. And you eat up an inheritance ravenously. And you love wealth with lavish love. (Q 89:15-20)

Similarly, the Prophet Muhammad on several occasions urged Muslims to give their surpluses to more unfortunate people, as evident in the following hadith:

Once we were on a journey with the Messenger of God when a rider came and began looking right and left. The Messenger of God said: "Whoever has an extra mount should offer it to him who is without it, and whoever has surplus food should give it to him who has nothing"; and he continued mentioning other properties until we thought that none of us had any right to surplus of his own property. ${ }^{22}$

What this tells us is that while the Islamic social justice system set up its own mechanisms of income redistribution and charity, the spirit behind the Basic Income is well supported by similar Islamic concepts. 


\section{Aims and Purposes of Islamic Law (Maqāșid al-Sharī'a)}

The objectives of Islamic Law are generally predicated on benefits to the individual and the community, and its laws are designed to protect these benefits and to facilitate the improvement of the conditions of human life on earth. The Qur'an echoes this priority when it singles out the most important purpose of the Prophethood of Muhammad: "We have not sent you but as a mercy to the worlds" (Q 21:107); the same can be seen in the Quran's characterization of itself as "a healing to the (spiritual) ailments of the hearts" and "a guidance and mercy" for the believers and humankind (Q 10:57). This very important objective of rahma (mercy or compassion) mentioned in these two verses is further substantiated by other provisions in the Qur'an and Sunnah that seek to eliminate prejudice, alleviate hardship, and establish justice. The laws of the Qur'an and Sunnah also seek to promote co-operation and support within the family and the society at large. The objective of rahma, therefore, is most clearly manifested in the realization of mașlaha (public benefit) ${ }^{23}$ in everyday communal life. The Muslim scholars have generally considered rahma to be the all-pervasive objective of the sharia, and, to all intents and purposes, used it synonymously with mașlaha. ${ }^{24}$

'Adl or qist (justice) is a manifestation of God's mercy, but may also be seen as a principal objective of the shari'a in its own right. Certainly the Qur'an sees it as such when it states: "We sent our Messengers and revealed through them the Book and the Balance so that Justice may be established amongst [hu]mankind" (Q 57:25). Justice as a value or primary objective of the shari'a is mentioned in the Qur'an fifty-three times in all. 'Adl (literally meaning "to place things in their right and proper place"), as a fundamental objective of the sharia, refers to seeking to establish an equilibrium between rights and obligations so as to eliminate all excesses and disparities in all spheres of life. ${ }^{25}$

We have argued above that, in an Islamic system, social justice is the duty of both society and the state. This vision is achieved in Islamic Law through a body of legal injunctions which carry specific objectives to be realized in narrower domains of human activity, such as economics, family life, or the political order. Muslim scholars have conceived this through concepts such as mașlaha and the objectives (maqāșid) of the sharia.

The eminent jurist al-Ghazali (d. 505/1111) stated that mașlaha "consists of considerations which secure a benefit or prevent a harm but which are, simultaneously, harmonious with the objectives (maqāșid) of 
the sharia." For al-Ghazali, these objectives "consist of protecting the five 'essential values,' namely religion, life, intellect, lineage and property. Any measure which secures these values falls within the scope of mastaha, and any which violates them is mafsada ('evil'), and preventing the latter is also mașlaha."26

Al-Shatibi (d. 790/1388) built upon the work of earlier jurists by arguing that the objectives of sharia can be divided into three levels: ${ }^{27}$

Necessities (al-darüriyāt): These are things humankind cannot dispense with, no matter the circumstances. The most important of these are the 'five universal necessities': religion, life, intellect, progeny, and property;

Needs (al-hājiyāt): These are things people use to fulfil major requirements of their lives; their absence leads to hardship and disorder, but does not bring about an end of life itself. Needs (mentioned three times in the Qur'an ${ }^{28}$ ) manifest themselves in the specific Islamic injunctions pertaining to commerce, marriage, and other forms of human transactions, ${ }^{29}$ but differ according to the time, place, and people; ${ }^{30}$ and

Niceties (al-takmiliyāt): These are things that beautify life, making it fuller and richer; Niceties include concerns such as dressing neatly, preparing food properly, and other good habits that shape human behaviour.

We can see that BI can be addressed under the first of these categories, where the relevant traditional categories seem to be those of "the destitute" (al-miskin) and "the poor" (al-faqir). Abu Hamid al-Ghazali said: "it is extremely difficult to define the exact amount for being 'self-sufficient' (ghani) whereupon it becomes forbidden to ask for help."31 The Prophet Muhammad said: "Whoever asks [for charity] when he [already] has enough to make him independent of means will have lacerations on his face on the Day of Resurrection." It was said: "O Messenger of Allah, what would make him independent of means?" He said: "Fifty dirhams or its equivalent of gold." ${ }^{32}$ The Prophet also said, "There is no right for the son of Adam except in these [four] things: a house to live in, a cloth to cover therewith his private parts, bread, and water." ${ }^{33}$ Based on this, al-Ghazali clarified the people's needs according to these three categories: shelter, food, and clothing. ${ }^{34}$ He extended this framework, commenting that the 'needy' who are eligible for charity include those who do not have sufficient for their needs, for the next day, for forty days, and a year. Substantively al-Ghazali suggested that five dīnārs might be sufficient for a single person in a year but not sufficient 
for a family. ${ }^{35}$ Five dinārs each equaled 4.25 grams of 24 -carat gold, totalling 21.25 for a single person for a year. This is Basic Income in medieval Islamic history. The requirements of the times and circumstances change, of course.

Thus, while Shatibi's contention that maqāșid could stand as an independent criterion for deriving law was not universally accepted, ${ }^{36}$ the division of public policy into categories addressing these three levels was. It is readily apparent that an Islamic state's requirement to provide for citizens' 'necessities' (darūriyāt), if not some aspects of 'needs' (häjiyāt), is wholly in accord with the advocacy for Basic Income doing the same thing.

\section{Islamic Concept of Wealth}

BI often falters over the question of cost, how a society could afford it. Advocates carefully think through what kind of taxation system could be fairly devised to support it. ${ }^{37}$ We do not propose here to investigate this question, leaving that to experts in taxation and accounting. However, it is useful to explain the Islamic concept of wealth, in order to demonstrate how a system that could sustainably pay for BI can be supported.

Wealth in Islam is not positioned at the center of the social order; rather, it is a tool of worship, used towards leading one's life in accord with Islamic principles. The Qur'an stresses that the ultimate aim of humankind's existence in this world is to obey God's commandments, thus enabling it to fulfill its role as vicegerent of the Almighty on earth. Therefore, all worldly resources constitute facilities and instruments for carrying out this mission; in other words, they are not desirable in and of themselves but as a means (essential or otherwise) to a noble end. However, it "does not mean that Islam dislikes or discourages economic pursuits... Islam places an equal emphasis on struggle and enterprise in worldly life and disdains asceticism... On the continuum of 'wealth as centre of all activities' and 'fatalistic abhorrence of this world', Islam stands somewhere in the middle." ${ }^{38}$

The Qur'an, in fact, recognizes people's natural inclination to possess; consequently, Islam permits individual ownership and considers wealth to be one of the indispensable necessities of human life. At the same time, Islam provides the necessary legislation to prevent the potential harmful effects of this inclination towards wealth, such as the loss of social equilibrium and the concentration of resources within a small sector of society. Some of the systems that Islam put in place to check human desire for wealth include the institutions of zakāt, the laws of inheritance, and social security. 
In Islamic law, the concept of wealth (al-māl) encompasses visible property, accumulated money, movable property, and an orphan's wealth. All these types of wealth can be either lawful or unlawful. While one's lawful possessions can include things with or without commercial value, the jurists considered wealth $(a l-m \bar{a} l)$ specifically as having "value with which it is exchangeable; and the destructor of it would be made liable to pay compensation; and what the people would not usually throw away or disown, such as money and the like." 39 The Hanafi school defines wealth (al-māl) as "a thing which is naturally desired by man [people], and can be stored for the time of necessity. It includes moveables (manqūl) and immoveables (ghayr manqūl)." ${ }^{40}$ The following qualifications of wealth emerge from these juridical definitions: it must (1) have commercial value; (2) be owned and possessed; (3) be stored; (4) be beneficial in the eyes of the sharia; and (5) have assignable and transferable ownership. ${ }^{41}$

\section{Spending Wealth}

One of the most important principles of the Islamic economic system is that wealth belongs to God alone, and human beings are merely entrusted with its use. The Quran speaks thus of giving to the poor: "give them some of Allah's wealth, which He has given you” (Q 24:33). As temporary trustees of God's wealth, it is incumbent upon any person to use any wealth in his/her possession within the confines set by Islamic law. Islam forbids the spending of wealth in unlawful ways, such as gambling, and encourages its spending in the way of charity. People are cautioned against letting their wealth tempt them into transgression, as it would lead to degradation and destruction (Q 17:16).

Furthermore, it is considered impermissible for people to squander their wealth on useless things. The Qur'an says: "Give the relative his due, as well as the needy and the traveler, and do not squander (your wealth) away. The squanderers have been brothers of the devils, and Satan has been ungrateful to his Lord" (Q 17:26-27). The Qur'an also warns those who hoard up wealth without spending it in worthy ways "of a painful punishment" (Q 9:34). So while Islam prohibits the hoarding of wealth that keeps it out of circulation, it encourages its investment and development, in order for wealth to fulfil its proper function in society.

Finally, Islamic financial interactions are structured around the principles of consent and justice. ${ }^{42}$ For example, contracts are not considered binding unless the contracting parties exercised their mutual consent and the contract's provisions are just (Q 4:29). 
With all these injunctions, Islam safeguards wealth from corruption and ensures it can fulfil its necessary and indispensable role in the order of human life. Together with other necessities of life, wealth facilitates the growth of civilization; however, as with other necessities, if wealth is not properly managed and preserved, it can lead to human civilization falling into ruin, and all its positive contributions coming to a halt.

\section{The Islamic Concept of Poverty (Faqr)}

Debates over BI are most especially focused on alleviating poverty, for advocates see in BI a better way to address poverty than current welfare systems. Likewise, Islam does not view poverty as a virtue, but as a social anomaly that must be alleviated, and a condition from which a Muslim should seek protection with God. In addition, like other world religions, Islam provides guidelines to eliminate the negative effects of poverty on society.

The various Islamic terms for poverty come from the root of the Arabic word faqr. There are two categories of poverty addressed in the literature: spiritual and material. An example of the former can be found in the following passage of the Qur'an:

Indeed you are those who are called to spend in the way of God, yet among you there are some who hoard. And whoever hoards, hoards only from his soul. And God is the Rich, and you are the poor. And if you turn away, He will exchange you for some other people. Then they will not be like you. (Q 47:38)

The majority of Qur'anic verses, however, address material poverty and call for helping, protecting, and sheltering poor people. The Qur'an recognizes the fact that those who are not wealthy have material needs and thus require other people's help to meet them.

Both the Qur'an and Muslim jurists have made a distinction between two categories of poor: al-faqì and al-miskin. The Hanafi school defined alfaqir as "the one who has less than the minimum amount of property liable to payment of the $z a k \bar{a} t,{ }^{\prime 43}$ that is, someone is considered al-faqi $r$ when he/ she does not have enough to suffice him or herself, meaning not having any wealth at all, and he/she is unable to earn their living by work suitable to them. Meanwhile, al-miskin is someone who has some wealth to spend on their needs, but that wealth is insufficient; for example, someone needs $\$ 5$ per day, but only has $\$ 3$ or $\$ 4$. This means that the considerations applicable to poor people also apply to people who may be short of money. ${ }^{44}$ 
Al-Shirazi, a Shafi'i scholar, says, "al-faqir is the one who cannot get what he needs to survive; in this case he is entitled to tolls to use it in work, if he is able to work, or commodity to trade; but al-miskin is the one who can get something for his needs but is not enough." ${ }^{45}$

Islam calls for one to lead a balanced life, encouraging the pursuit of wealth while cautioning against it becoming the main aim of a person's life, or else a source of pride, arrogance, and oppression of others (all these being strongly condemned in the Qur'an and hadith). In the spirit of that balance in society, Islam argues for the elimination of poverty and introduces several ways to achieve this purpose. This means that Muslims living in a society not implementing the special systems of zakät and charity meant to lessen poverty can, and should, support public policy, such as BI, aimed at the same goal.

Work

One of the biggest stumbling blocks for BI, both the Negative Income Tax and Demogrant model (indeed, more so the latter), is the idea of de-linking income from work. For reasons special to Western capitalist history, work has become linked to income and a person's identity, ignoring the importance of beneficial unpaid work. Some argue this is related to a secularized Protestant Work Ethic. ${ }^{46}$ Thus BI is opposed for its giving people "something for nothing," that people will be taking advantage of others' labor.

Islam also points out the beneficial aspects of work ('amal), meaning that beneficial and permissible effort which culminates in appropriate earnings meant to cover a person's life expenses. The importance of work is mentioned several times in the Qur'an, as in Q 62:10: "And when the prayer has finished, then spread out in the land and seek God's bounty." Likewise, several hadiths emphasize the virtue of work, pointing out that the best earnings are those that come from one's own hand. Some examples include, "No man earns anything better than that which he earns with his own hands; and what a man spends on himself, his wife, his child, and his servant, then it is charity;" ${ }^{47}$ and, "It is better for anyone of you to carry a bundle of wood on his back and sell it than to beg of someone whether he gives him or refuses." ${ }^{8}$ These hadiths articulate the Islamic position that struggling for a living by producing goods and services, or by commerce, is a meritorious job. In fact, working to obtain property and maintain a good life is considered part of worship ('ibāda).

Two important principles guide and regulate this encouragement to work: (a) gaining income and ownership should be done by legal means; 
and (b) income and wealth should be spent on legal aims and the attainment of common good. Islam condemns those who accumulate property for the purpose of greed and oppression, as well as those who gain wealth through unlawful business practices.

The importance of hard work and entrepreneurship in earning one's living is amply illustrated in the following hadith:

A man of the Ansar came to the Prophet (peace and blessings upon him) and begged from him. He (the Prophet) asked: Have you nothing in your house? He replied: Yes, a piece of cloth, a part of which we wear and a part of which we spread (on the ground), and a wooden bowl from which we drink water. He said: Bring them to me. He then brought these articles to him and he (the Prophet) took them in his hands and asked: Who will buy these? A man said: I shall buy them for one dirham. He said twice or thrice: Who will offer more than one dirham? A man said: I shall buy them for two dirhams. He gave these to him and took the two dirhams and, giving them to the Ansari, he said: Buy food with one of them and hand it to your family, and buy an axe and bring it to me. He then brought it to him. The Apostle of Allah (peace be upon him) fixed a handle on it with his own hands and said: Go, gather firewood and sell it, and do not let me see you for a fortnight. The man went away and gathered firewood and sold it. When he had earned ten dirhams, he came to him and bought a garment with some of them and food with the others. The Apostle of Allah (peace be upon him) then said: This is better for you than that begging should come as a spot on your face on the Day of Judgment. Begging is right only for three people: one who is in grinding poverty, one who is seriously in debt, or one who is responsible for compensation and finds it difficult to pay. ${ }^{49}$

Earning one's living being a noble pursuit, and leaving aside the gendered aspects of the dual-sex society envisaged by classical sharía, in which the husband is the main breadwinner and the wife focused on unpaid work in the home, Islam establishes every individual's right to work and holds the state responsible of providing work for those who are otherwise unable to find it. Furthermore, Islam asserts the honour and nobility of the worker and makes fulfilling his/her material and intangible rights an obligation. Among the rights of workers are wages that are fair and adequate in terms of fulfilling basic needs. The Prophet said: "Whoever is appointed to work for us and does not have a home should be given a home. If he does not have a wife, he should be given the means to marry; and if he does not 
have a mount, he should be provided with one." ${ }^{50}$ Not only is this statement indicative of $\mathrm{BI}$, it also supports the arguments for the principle of the minimum wage.

This emphasis on work is why many Muslims will object strongly to the concept of the Demogrant, as it clearly gives money to those who are not in material need. There is not space here to develop a Muslim argument for the Demogrant at depth, but suffice it to say that if it can be properly demonstrated that the poor benefit best, paradoxically, from a system that also gives money to those not in material need, then it should be given serious consideration. Moreover, as the 'employment' trap articulated by Van Parijs works out, there may be other important human needs (such as time for family) that add favor to this point of view. Importantly, we should note that unlike the BI debates, Muslims do not connect giving charity with any kind of workfare or EI requirement that links searching for work and receiving basic needs income. At the very least the Negative Income Tax model, which closely mirrors that of zakät, can earn the support of Muslim citizens in Western democracies.

\section{Economic Justice}

The teachings of the Qur'an establish clearly the superiority of spiritual wealth over any material wealth, and remind humanity of its status of custodians of the things of this world, all of which are bestowed on it by God. The Qur'an warns: "But whoever has hoarded and thought himself rich, And rejects goodness, We will ease him into grief. His riches will not enrich him when he falls (to the Fire)" (Q 92:5-11). ${ }^{51}$

In every community, some people are better at economic and financial affairs, while others excel in different spheres; some seem to possess an abundance of talents and abilities, while others struggle even with the basics of self-care. The analogy of a community being as a single body is prominent in Islamic teachings, and one of its wisdoms is the recognition that people contribute to society differently. Not everyone can be the eyes or the hands; rather, individuals should apply themselves towards reaching the highest degree of self-development, for their own sake and in the service of their community. Work performed in the spirit of service is a form of worship, just as prayer is, because it is a realization of faith through action. Indeed, the pursuit of one's talents and abilities in work and service should go hand-in-hand with the awareness of God as the ultimate Sustainer of all affairs. 
The understanding of work as worship is quite different from the neoclassical economic concept of the "invisible hand" which (falsely) assumes that if all parties work for their own self-interest, all will be satisfied. Today such thinking is widely fostered in an attempt to lend moral justification to selfish behavior. However, reliance on selfish notions of "the invisible hand" and free markets is actually destroying economies and lives. Were employers to consider the lives of their employees' families as important and dear to them as their own, would they continue laying people off indifferently? How can physicians demand outrageous fees from the poor to administer life-saving treatments? How can the rich live in self-satisfied comfort and luxury while knowing that others are in dire want, sometimes on their very doorstep? Building society on the power of self-interest is not the solution; true generosity is necessary to balance affairs.

The wealthy and the poor alike must be provided for, in dignity, lest either wealth or poverty impinge upon the self-respect of the human station..$^{52}$ The Qur'an has instituted charity (zakāt) as a means of making the process easier for both the giver and the receiver of charity. As the Quran says, "Take alms from their wealth to purify them and make them grow by them. And pray for them. Your prayers are calmness for them. Allah is All-Hearing, All-Knowing" (9:103). The wisdom of the institution of zakāt recognizes that forcing a person to ask for aid from another can be degrading and humiliating, while God wishes for His servants to live in dignity and repose and does not wish humiliation upon any soul. In the same spirit of dignity, economic justice requires adjusting of individual incomes so that no one has too much or too little, lest that extreme wealth lead its possessor into ways of perdition, while the one in dire want endures a humiliating life. Thus a BI system can contribute towards that dignity and balance.

\section{Part Two:}

\section{Basic Income: Islamic Perspective on Sources of Revenue}

\section{The Welfare-Tax (al-Zakāt)}

There is nothing more horrifying than the realization that as we live our lives happily, millions of our fellow human beings continue to live in need and hunger-and yet, the majority of the world's population today lives in poverty. It is evident that the economic system dominating our world is unjust and inhumane. How can we allow less than 10 percent of the world's population to continue controlling over 90 percent of the earth's wealth and resources? It is partly due to this that BI, for which some have advocated for 
over thirty years, is being seriously considered again, as the welfare state is clearly not effectively alleviating poverty.

As mentioned above, BI often stumbles over the difficulties of how it will be paid for. Muslims are quite familiar with the notion and practice of paying an annual amount to address poverty through the institution of zakāt. ${ }^{53}$ The Qur'an (9:60) makes it obligatory on every Muslim to pay annually a certain "alms tax," at the rate of 2.5 percent on all un-invested wealth like silver, gold, jewellery (according to Hanafi Law), cash, commercial goods, and debts receivable. There are rules on how to pay zakät on each type of possessions (gold, animals, crops, shares, and so on). Zakāt is not imposed on the value of built-up houses, tools of the trade (including industrial machinery), and agricultural implements. The money collected from $z a k \bar{a} t$ is intended to be distributed among the poor and needy. The Arabic word itself means both 'purification' and 'growth.' As noted above, one of the most important principles of Islam is that all things belong to God, and wealth is therefore held by human beings in trust only. This wealth is 'purified' by setting aside a proportion for those in need; like the pruning of plants, this cutting back of one's wealth balances it and encourages new growth.

Zakat is due on accumulated wealth that has been in the possession of a person for at least one year. It is not paid on income required for daily needs; therefore, people who save nothing after covering their expenses with their income do not pay zakāt, and in fact may be eligible to receive zakāt payments from others if their income does not cover all their basic needs.

Zakāt is to be distributed among people of the following categories, depending on need:

1. The Destitute: those who do not have material possessions nor means of livelihood;

2. The Poor: those with insufficient means of livelihood to meet basic needs;

3. The Indebted: those who are in debt and have difficulty repaying it;

4. Stranded Traveller: the traveller who does not have enough money to complete their journey;

5. To Free Slaves: zakāt money is to be used to manumit slaves them; 
6. New Muslims: those who are new to Islam and require help to integrate themselves into the Muslim community;

7. In the Path of God: a broad category that can include any project that helps the Muslim community or champions Islamic causes;

8. Zakāt Workers: those whose job it is to collect and re-distribute zakat funds also draw their salary from zakāt.

In addition to the obligatory zakāt described above, Islam greatly encourages Muslims to give extra charity. The Prophet Muhammad once said that the person who sleeps with a full stomach while his neighbour sleeps hungry is not a true believer. ${ }^{54}$ There is a requirement for people who are not able to fast in Ramadan to feed the poor for each day they do not fast; one of many other examples of Islamic charity is sadaqat al-fitr, which is given to poor and needy people to ensure they fulfill their basic need in the day of Muslim celebration of Eid.

Being thus familiar with the idea of the wealthy supporting poor people for some of their needs, Muslims should find it natural to support the implementation of a BI.

\section{Natural Resources and Ownership}

Birnbaum ${ }^{55}$ and others argue that a BI should be funded in part from taxes on natural resources. The idea is that some people benefit unfairly from profits gleaned from access to natural resources, whereas the fruits of such resources belong to humanity as a whole. The BI component is a rent owed to the non-owners of the enterprise that is making profit from extraction. Islamic law has made a similar distinction, at least between the concept of visible and invisible resources that can be privately owned versus publicly owned. ${ }^{56}$ The view on natural resources in Islam is that everything created by the Creator in this earth is permissible for use and has its benefit. Visible resources include minerals, forests, water, and fertile land that occur in nature and can be used for economic gain. Invisible resources include gas, oil, gold, silver, etc., or else other kinds of buried treasure.

The Prophet said, "Muslims share three things: water, pasture and firewood." 57 This suggests that in Islam, such public natural resources are to be shared by all humanity, and it is unlawful for anyone to take them away or deprive others from using them. In addition, contemporary jurists have ruled that a public interest exists in certain invisible resources such as oil and gas, meaning that these cannot be privately owned even if found 
on private land (in such cases, reimbursements are given to the land owner). So, Muslims ought not be averse to the notion of partly funding a BI through taxation on natural resources.

\section{Endowment (Waqf)}

Proponents of BI often come up against the problem of how costly it might be and how to fund it. One solution which is not often discussed in western debates could be drawn from the Islamic practice of charitable endowments. Waqf (pl. awqāf), which lexically means 'to be retained', is a legal term for the appropriation or dedication of property to charitable uses and the service of God, entailing an endowment or appropriation of a perpetual nature (such that the property or land cannot be sold or transferred). It refers to the retention of any property that can be benefited from while the property itself still remains, its financial proceeds going to some permissible expenditure. ${ }^{58}$ Its scriptural basis lies in the hadith related by Muslim that the Prophet said: "When a human being dies, his work comes to an end, except for three things: ongoing charity, knowledge benefited from, or a pious son who prays for him." ${ }^{59}$ Scholars understand endowments (awqāf) as the 'ongoing charity' referred to here.

When Q 57:11 ("Who is he that will lend God a goodly loan? He will multiply it for him, and he will have a generous reward") was revealed, Abu al-Dahdah (Allah be pleased with him) said, "Does Allah really ask His slave for a loan, O Messenger of Allah?" He said, "Yes." He said, "Stretch forth your hand, O Messenger of Allah," and he asked him to bear witness that he was giving in charity his garden, besides which he owned nothing else, and in which there were seven hundred fruit-bearing palm trees. Then he went back to his wife, who lived with their children in that garden, and told them what he had done, and she and the children left that garden; she said to him: "What a profitable sale you have made, O Abu al-Dahdah!"60

Also, when Allah revealed the words "You will not attain piety until you give some of what you love away" (Q 3:92), Abu Talha al-Ansari said: "O Messenger of Allah, the most beloved of my wealth to me is the well of $h \bar{a}$ ' bir h $h \bar{a}$, a well which gave good water-and (I give it) in charity for the sake of Allah, hoping that it will be stored with Allah. So, O Messenger of Allah, do with it as Allah shows you." The Prophet said: "Well done! That is a profitable deal, that is a profitable deal. Freeze the principle (land) and give the fruits in charity."61

This act of charity was the first waqf in Islam. From here the phenomenon of waqf developed, which is what supplied all the social institutions 
with the financial resources that helped them to fulfil their noble humane missions. The waqf was the foundation on which all the charitable institutions in our civilization's history were built. The Messenger of Allah was the first to set the sublime example to his umma. He gave as a waqf seven gardens which one of the warriors had bequeathed when he died, saying that the Messenger should dispose of them in whatever manner he chose. So the Messenger of Allah set them up as a waqf for the poor and needy. His example was followed by 'Umar ibn al-Khattab, who gave his land at Khaybar as a waqf; and by the Companions Abu Bakr, 'Uthman, 'Ali, al-Zubayr, Mu'adh, and others, until there was no Companion who had not given some of his wealth as a waqf. This humane action was revived during the Caliphate of 'Umar, when he gave some land as a waqf for the sake of Allah when he was the Caliph, and he called together a group of the Muhājirīn and Anșār and asked them to bear witness to that. Jabir ibn 'Abdullah al-Ansari said: "I do not know of anyone among the Companions of the Messenger of Allah who had the means to do so, whether from among the Muhājirin or the Anșār, who did not give some of his wealth as a waqf that was not to be bought, inherited, or given away".

Then the Muslims continued to do that, generation after generation, giving land, gardens, houses and crops as waqfs for good works, which filled Islamic society with innumerable charitable foundations. ${ }^{62}$

\section{Part Three: Historical Examples of Basic Income}

The public treasury, or the House of Wealth (bayt al-māl), was established as a financial institution in the first Islamic state. It was a place that stored whatever revenues and any other amounts received by the state, which were then immediately distributed to its citizens. This was the practise of the Prophet and of the four leaders (caliphs) that came after him. ${ }^{63}$ 'Umar, the second caliph, would distribute all remaining wealth in the public treasury yearly after a final calculation. ${ }^{64} \mathrm{He}$ established an office known as the Account Books of the Treasury (dìwān al-'ața'). The fourth caliph, 'Ali, used a different approach: he would distribute all wealth remaining in the treasury department every Friday ${ }^{65}$ These practices sound very much like early examples of a Basic Income.

Some anecdotes from the lives of the early caliphs are instructive. Caliph 'Umar once saw an elderly man in the marketplace asking for charity. This mendicant was one of the Jews who lived in Medina, and he spoke thus to the caliph: "I am an old man who is asking for help in paying the jizya (tribute) and in spending on my own livelihood." 'Umar said to him: 
"We have not been fair to you, old man. We took the jizya from you when you were young, then we neglected you when you grew old." 'Umar then took the Jewish man by the hand and led him to his house, where he fed him from his own food. 'Umar sent word to the keeper of the bayt al-māl (treasury of the Islamic state), saying to him: "Give an allowance to this man and others like him, so that he and his children will be independent." 66 This is a great example of a state leader ensuring personally that the state fulfils its responsibilities.

\section{Conclusion}

This research is a tentative beginning in providing some Islamic perspectives on the current debates over Basic Income. We have demonstrated that social and economic justice is part and parcel of the Islamic religion. Section one discussed concepts of wealth, poverty, and work to show that the Qur'an emphasizes the desirability of work and the necessity of helping the poor. The importance of the latter is captured in the core principles of maqāșid al-sharī ${ }^{-} a$ (also discussed in section one), which call on the Islamic state to provide a basic level of sustenance for its citizens. In considering the above concepts together, one recognizes that wealth is given to humanity as a trust from God; in order to manage that trust in a way that avoids the two extremes of excessive wealth and crushing poverty, a tax and welfare system has been developed by Islamic law. We suggested that it is because of this comprehensive nature of Islamic law that Muslims have not participated in the Basic Income debates; but a review of some of the main themes demonstrates that while the rationale and revenue streams of the Western concept of Basic Income might not be the same as those offered in Islam, there is much symmetry between the two concepts, and further research is needed to explore their similarities. Section two and three examined Islamic perspectives on how such funds would be raised, along with some very brief historical examples of state wealth management in early Islamic history. 


\section{Endnotes}

1. “The President in Conversation With MIT's Joi to and WIRED's Scott Dadich,"Wired, https://www.wired.com/2016/10/president-obama-mit-joi-itointerview/.

2. An election of a new government in September 2018 saw this pilot cancelled.

3. Karl Widerquist, José A. Noguera, Yannick Vanderborght, and Jurgen De Wispelaere (eds), Basic Income: An Anthology of Contemporary Research (Chichester, West Sussex: John Wiley \& Sons, 2013).

4. $\quad$ E.g. Muhammad Nejatullah Siddiqui, “The Guarantee of a Minimum Level of Living in an Islamic State," in Distributive Justice and Need Fulfilment in an Islamic Economy, ed. Munawar Iqbal (Leicester, UK: The Islamic Foundation, 1988); Shafinah Rahima, "Distributive Justice: A Perspective from Islamic Economics Literature," Journal of Emerging Economies and Islamic Research 1, no. 3 (2003).

5. Siddiqui, "Guarantee of a Minimum Level of Living," 24.

6. See Hugh D. Segal, A Basic Income Pilot Project for Ontario: A Discussion Paper (Toronto: Massey College, 2016); Ontario Government website on the project, https://www.ontario.ca/page/ontario-basic-income-pilot.

7. Segal, Basic Income Pilot Project, 15, 21.

8. Philippe Van Parijs, "A Basic Income for All," in What's Wrong With a Free Lunch, ed. Joshua Cohen and Joel Rogers (Boston: Beacon Press, 2000).

9. Sally Lerner, CMA Clark, and WR Needham, Basic Income: Economic Security for All Canadians (Toronto: Between the Lines, 1999), 13.

10. Bo Rothstein, “UBI: A Bad Idea for the Welfare State," https://www.socialeurope.eu/ubi-bad-idea-welfare-state.

11. Widerquist et al., Basic Income.

12. Azmi, Islamic Economics 23, no. 2 (the Islamic Research and Training Institute, Saudi Arabia, 2015): 40.

13. Muhammad Said Ramadan al-Buti, Women Between the Tyranny of the Western System and the Mercy of Islamic Law, trans. Nancy Roberts, ed. Anas al-Rifai (Damascus: Dār al-Fikr, 2006), 27, 119.

14. Azmi, Islamic Economics, 41.

15. al-Nawawi, Minhāj al-Ṭālibìn wa 'Umdat al-Muftin (Cairo, 1343 AH), 125.

16. Abu Hamid al-Ghazali, al-Tibr al-Masbūk fī Nașīhat al-Mulūk (Cairo, 1306 $\mathrm{AH}), 94$; Azmi, Islamic Economics, 41.

17. In al-Bukhari and Muslim (1, no. 224); http://library.islamweb.net/hadith/ display_hbook.php?bk_no=158\&pid=108221\&hid=4691.

18. Ibid., with alteration.

19. Abu Zahra, Tanzīm al-Islām li-l-Mujtama'(Cairo, n.d.), 17-18; Tufail Ahmad Qurashi, "Justice in Islam," Islamic Studies 21, no. 2 (Summer 1982): 38. 
20. A. Hasan, "Social Justice in Islam," Islamic Studies 10, no. 3 (September 1971):209.

21. Ibid.

22. Muslim, Șaḥiḥ, vol. 1, Hadith 566 (http://library.islamweb.net/newlibrary/ display_book.php?flag=1\&bk_no=79\&ID=7761\#docu).

23. Literarily, mașlaḥa means 'benefit' or 'interest'. It is often rendered as 'public interest', although it is much closer in meaning to well-being, welfare, and social welfare. We have opted to use the Arabic term throughout.

24. Mohammad Hashim Kamali, Principles of Islamic Jurisprudence (Kuala Lumpur: Islamic Book Trust, 2000), 395-396, with modifications.

25. Ibid.

26. Abu Hamid al-Ghazali, al-Muștașfā (Beirut, 1413 AH), 1:174; Kamali, Principles of Islamic Jurisprudence, 267, and references cited there to Khallaf and Badran.

27. Jasser Auda, Maqāșid al-Sharīah: A Beginner's Guide (Herndon, VA: International Institute of Islamic Thought, 2008); Muhammad Khalid Masud, Shatibi's Philosophy of Islamic Law (New Dehli: Kitab Bhavan, 1997).

28. Namely, Q 12:68: “it only being a need of Jacob's soul which he had met”; Q 59:9: "and do not feel a thing in their breasts for what the (movers) have been given"; and Q 27:62: "Is not He (best) Who answers a wretch when he calls to Him and removes the evil."

29. Abu Ishaq al-Shatibi, al-Muwāfaqāt fī Ușūl al-Sharīa (Beirut, n.d.), 2:10-11; al-Razi, Mukhtār al-Ṣiḥāh (Cairo), 160, 379; Muhammad Rawas Qal'aji, alMawsū'a al-Fiqhiyya (Beirut, 2005), 1:695.

30. Ibid.

31. Abu Hamid al-Ghazali, Ihyyā' 'Ulūm al-Dīn (Cairo, 1992), 4:268.

32. al-Nasa'i, Sunan al-Nasā'i, http://library.islamweb.net/newlibrary/display_ book.php?flag=1\&bk_no=57\&ID=3198\#docu.

33. 'Isa al-Tirmidhī, Sunan al-Tirmidhī (Beirut, n.d.), 1:1, http://library.islamweb.net/newlibrary/display_book.php?idfrom $=2263 \&$ idto $=2263 \& b k$ _ no $=2 \& \mathrm{ID}=1574$.

34. al-Ghazali, Ihy $\bar{a}, 4: 268$.

35. Ibid., 4:269.

36. Ibid.

37. Lerner, Clark, and Needham, Basic Income.

38. https://www.islamicbanker.com/education/concept-wealth.

39. Muhammad Wohidul Islam, "Al-Mal: The Concept of Property in Islamic Legal Thought," Arab Law Quarterly 14, no. 4 (1999): 364, and references cited there to al-Suyuti.

40. M. al-Zuhayli, al-Fiqh al-Islāmī wa Adillatuh (Damascus, 2007), 4:2877; Islam, "Al-Mal," 363.

41. Ibid, with some alteration; al-Zuhayli, al-Fiqh al-Islāmī, 4:2876. 
42. M. A. Khan, "Consumer Protection and the Islamic Law of Contract," Islamabad Law Review 2, no. 2 (November 2011), 21.

43. 'Abd al-Rahman al-Juzari, al-Fiqh 'alā al-Madhāhib al-Arba'a (Beirut, 2004) $1: 523$.

44. Ibn al-Naqib Ahmad, 'Umdat al-Sālik, trans. Nuh Keller (UAE, 1991), 267, 269; al-Shirazi, al-Muhadhab (Beirut, n.d.), 1:170-173; al-Bahuti, Kashshäf al-Qināc (Beirut, 1983), 2:316; Ibn Qudama, al-Mughnī (Cairo, 1997), 2:665.

45. Ibrahim b. 'Ali al-Shirazi, al-Muhadhdhab fī Fiqh al-Imām al-Shāfi' (Beirut, 2005), 1:238.

46. Chandra Pasma, Working Through the Work Disincentive (Ottawa: Citizens for Public Justice, n.d.).

47. Ahmad b. 'Ali b. Hajar al-Asqalani, al-Talkhīṣ al-Habìr fì Takhrīj Ahāàìth al-Räfì al-Kabir (Cairo, 1994), 3:5.

48. al-Bukhari and Muslim, 1, Hadith 540.

49. Abu Dawud, Sunan Abū Dāwūd (Beirut, 2009), 9:86.

50. Ibid.

51. Again, Q 3:92: "You will not attain piety until you give some of what you love away. And whatever you give away, Allah knows it well."

52. Ansari, The Qur'anic Foundations and Structure of Muslim Society (Pakistan, 2008), 3, 13.

53. Indeed, we believe that if a zakāt system were to be implemented worldwide, the problem of poverty, hunger and starvation could be completely eliminated within a year. The zakāt due on agricultural products ranges from $5 \%$ to $10 \%$ of the produce; there is also zakāt due on various types of animals such as sheep, cows, and camels. If $5-10 \%$ of all agricultural production in the world, plus the required amounts due on animals, were distributed among the most poor, the problem of hunger would be solved. Under the current system we have, some nations intentionally spoil a part of their agricultural production in order to maintain high prices for their produce; this betrays it to be a system driven by human greed rather than one guided by the Almighty, who is Most Gracious and Most Merciful. Zakät due on money can further solve the poverty problem. Zakāt is due at $2.5 \%$ on money that has been in one's possession for over a year. Forbes Magazine reported that in 2014 , there were 500 billionaires worldwide, with a combined net worth of $\$ 6.4$ trillion dollars. If, for instance, these 500 richest people in the world had paid zakāt in 2014, there would have been $\$ 160$ billion dollars available to distribute among the poor. This simple calculation has only involved 500 wealthy individuals; we could only imagine what can be accomplished if everyone contributed to a global zakät fund in the same way. The total world GDP (summation of gross domestic product of all countries in the world) was estimated in 2014 to be $\$ 77,301.958$ billion dollars; the $2.5 \%$ zakät on this would amount to $\$ 683.95$ billion dollars. These are just estimates, but 
they offer an idea of how much money zakät can generate. Zakāt money could not only be distributed for immediate relief to the poor; it can also be given in the form of small business loans. Poor farmers, for example, can be given loans or grants from the zakät fund to enable them to purchase equipment and materials they need to lift them out of poverty. The same can be done for small business owners, or for skilled artisans and laborers to set up small workshops or factories. Such incentives could, within a few years, if not eliminate poverty, then at least dramatically reduce it.

54. 'Ali b. Abi Bakr Ibn Hajar al-Haythami, Mu'jam al-Zawäid wa Manba' alFawäid (Cairo, 1994), 8:170.

55. Simon Birnbaum, Basic Income Reconsidered: Social Justice, Liberalism and the Demands of Equality (New York: Palgrave Macmillan, 2012).

56. al-Khuli, al-Tharwa fì Dill al-Islām (Kuwait, n.d.), 225-226.

57. Abu Dawud, Sunan, 3477, (http://library.islamweb.net/newlibrary/display_ book.php?idfrom $=1816 \&$ idto $=1819 \& b k \_n o=47 \& I D=761$ ).

58. Ibn al-Naqib, 'Umdat al-Salik, 453-454.

59. Muslim, Șahīh 13:8 (http://www.islamweb.net/hadith/display_hbook. php?bk_no=213\&pid=50959\&hid=426).

60. Tafsir Ibn Kathīr (http://quran.ksu.edu.sa/tafseer/katheer/sura2-aya245. html).

61. Tafsìr Ibn Kathìr (http://quran.ksu.edu.sa/tafseer/katheer/sura2-aya245. html).

62. For more, see, al-Siba'i, Min Rawāì Hadāratina (Beirut, 1977), 124.

63. Known in the Sunni perspective as the "Rightly-Guided Caliphs."

64. Ibn al-Jawzi, Manāqib Amīr al-Mu'minīn 'Umar b. al-Khaț̣āb, 79.

65. Abu al-'Abbas al-Nasiri, al-Istiqsā' li Akhbār Duwal al-Maghrib wa al-Aqșā', $1: 112$.

66. al-Siba'i, Min Rawāì' Haḍāratina, 67. 